\title{
Energy storage technologies for building applications
}

\author{
Abdülkadir Çakır ${ }^{1 *}$, Ertuğrul Furkan Kurmuş ${ }^{1}$ \\ ${ }^{1}$ International University of Sarajevo, Bosnia

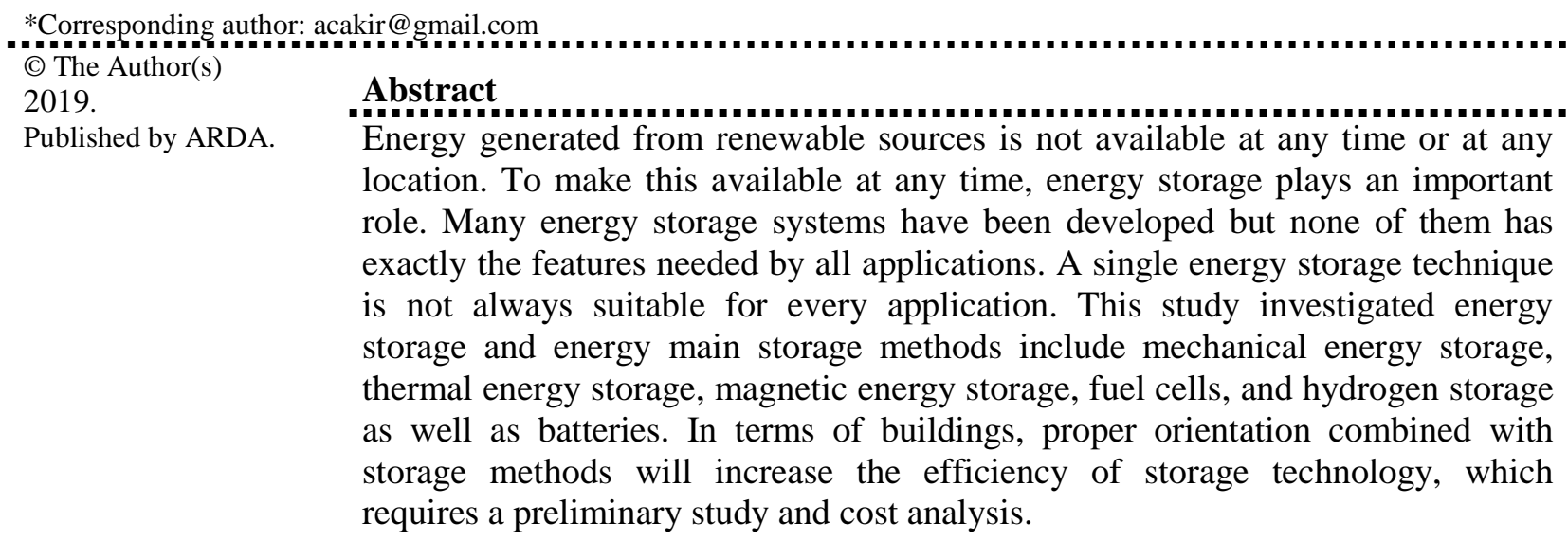

Keywords: Energy storage technologies, Mechanical energy storage, Electrical energy storage, Thermal energy storage

\section{Introduction}

While defining energy precisely is one of the most difficult things in physics, in its simplest definition, energy is what makes it possible for everything to happen around us. More technically, energy is the name given to the ability of substances to do work. Substances can only change their existing physical state by using energy. Observable operational energy is called kinetic energy. Energy can be found in many different places and shapes. It is possible to talk about many types of energy in nature. Although scientists have been describing different types of energy for many years, it is possible to define new types of energy as science and technology progress over time. Today, the most commonly defined types of energy are:

Mechanical energy: It is the name given to the total energy of mechanical systems that can contain both potential and kinetic energies; Nuclear energy: It is the type of energy obtained from the mass difference in the reaction of atomic nuclei. The lost mass is completely converted into energy. Nuclear energy can be obtained by combining atoms as well as by fusing them and is divided into fission and fusion energy;

Chemical energy: It is the kind of energy produced by the chemical reaction of different substances. Batteries or gas oil used for heat / light are examples of chemical energy use; Magnetic energy: This is the kind of energy caused by the magnetic force released by the movement of electrons; Heat energy: The name given to the energy transmitted to increase the temperature of a substance. It is carried out by heat transfer from a material with a higher temperature to the lower temperature. It can be obtained by burning various fuels;

Gravity Energy: It is the energy that provides useful work as a result of gravity; Electrical energy: Electricity is one of the most common types of energy that we interact with in our lives. It is a kind of energy which is formed by the movement of the free electrons in the metals under the electrical potential difference. As many different types of energy in the electric energy is generally used in the manufacture of another type of energy. When energy is used, it is transformed from one kind of energy to another. For example, the gravitational energy of the water that falls during the dams is converted into mechanical energy when the turbine is rotated. This mechanical energy is converted into electrical energy in the generator at the end of the rotating turbine. Electrical energy is transformed into different types of energy when used[1].

This work is licensed under a Creative Commons Attribution License (https://creativecommons.org/licenses/by/4.0/) that allows others to share and adapt the material for any purpose (even commercially), in any medium with an acknowledgement of the work's authorship and initial publication in this journal. 


\subsection{Importance of energy storage}

Today, the energy demand arising from the increasing population and industrialization cannot be met with the limited resources of our planet and the difference between the energy production and consumption is growing rapidly. In this case, it becomes increasingly important to utilize our energy resources more effectively. In order to meet the rapid increase in energy demand, it would be beneficial to efficiently store the energy obtained from renewable energy sources and to develop the most suitable transformations to meet the need [2]. In parallel with the increase in world population and living standards, energy consumption is increasing at the same rate. The total energy consumption in the world according to the foreseen 2005-2030 projections is expected to increase by 50\% [3]. This increase is due to the limited amount of fossil fuels that have the largest share in energy production and the increase in the amount of waste resulting from their use brings along many economic and environmental problems. Therefore, it increases the need for new energy resources and especially the use of renewable energy resources and the efficient use of energy resources [4]. Energy storage methods used for the efficient use of energy can contribute to the reduction of the consumption of fossil fuels and to the effective use of new sources and renewable energy sources. Ensuring supply demand balance, increasing the efficiency of the energy system, saving energy and contributing to energy storage are some of the contributions [5]. It aims at storing the waste energy generated in the areas where energy is used and, on the other hand, by storing only the energy of energy sources that can give energy at certain times, and eliminating the difference between supply time and demand. Thus, the efficiency of energy systems is increased and energy savings are ensured. For example; reuse of thermal energy in winter; $22 \%$ in heating systems can achieve an energy saving of up to $40 \%$ in summer months with the same method [2]. It plays an important role in preventing environmental damage caused by the fuels used for energy production. Due to less fossil fuel consumption, the amount of greenhouse gas emitted into the environment will be reduced and thus a cleaner air will be inhaled.

\section{Energy storage methods}

It is desirable that the energy is ready for use at any time and at the desired location. To use the energy whenever it is needed is called storing it. This storage can take several forms. Features required in a storage; high storage capacity, high charge / discharge efficiency, low self-discharge and capacity losses, long life, cheapness, energy intensive ( $\mathrm{kWh} / \mathrm{kg}$ or $\mathrm{kWh} /$ liter). In other words, it should be able to store energy in minimum volume and weight [6]. There are some important points for the efficient use of energy storage technologies. Those are: 1. Increasing efficiency in energy system resources; 2. Ensuring integration between different renewable energy sources (especially wind and sun); 3. Increasing internal consumption and internal production of energy (electricity, heating / cooling) (without giving to main systems); 4. Increasing the use of electrical energy by end-users (electric vehicles, etc.); 5 . Increasing access to energy (Electricity-independent electricity, etc.) 6. Ensuring stability, reliability and flexibility in networks [8]. When energy is used, it is transformed from one kind of energy to another. When a battery is used, chemical energy is converted into electrical energy; a part of the potential energy in the water flowing from a waterfall turns into kinetic energy, while some remain kinetic energy. Energy storage is the storage of energy to use when we want. This storage can take a variety of forms and is a set of techniques where different methods are used as a common rather than a single technological method [9]. These energy types are given below and detailed comparison of these energy applications is given in Table 1 .

Table 1 : Different Storage Technologies and Basic Features [9]

\begin{tabular}{llll} 
Technology & $\begin{array}{l}\text { Energy } \\
\text { Output }\end{array}$ & Efficiency & $\begin{array}{l}\text { Cost } \\
\text { (USD/kW) }\end{array}$ \\
\hline Flywheel & Electricity & $90-95$ & $130-500$ \\
Pumped Hydro-Power & Electricity & $50-85$ & $500-4600$ \\
Compressed Air Energy Storage & Electricity & $27-70$ & $500-1500$ \\
Super Capacitors & Electricity & $90-95$ & $130-515$ \\
Super Conductive Magnetic Energy Storage & Electricity & $90-95$ & $130-515$ \\
Thermal Energy Storage & Thermal & $90-99$ & $1000-3000$ \\
Hydrogen Energy Storage & Electricity & $30-50$ & $550-4500$ \\
\hline
\end{tabular}




\begin{tabular}{llll} 
Technology & $\begin{array}{l}\text { Energy } \\
\text { Output }\end{array}$ & Efficiency & $\begin{array}{l}\text { Cost } \\
\text { (USD/kW) }\end{array}$ \\
\hline Batteries & Electricity & $75-95$ & $900-3500$ \\
Underground Thermal Energy Storage & Thermal & $50-90$ & $3400-4500$ \\
Molten salts & Thermal & $40-93$ & $400-700$ \\
Chemical - Hydrogen Storage & Electricity & $22-50$ & $500-750$ \\
Solid State Media Storage & Thermal & $50-90$ & $500-2000$ \\
Ice Storage & Thermal & $75-90$ & $6000-15000$ \\
Hot and Cold Water Storage & Thermal & $50-90$ & $300-600$ \\
\hline
\end{tabular}

\subsection{Mechanical energy storage}

By applying force to a material system, there are two basic systems for storing the energy generated by this force. The first is related to the change in potential energy, while the second is related to the energy, i.e. kinetic energy, which is the result of the movement of the mass. These two energies can be transformed into each other or transformed into heat energy or work [10].

\subsubsection{Flywheel storage}

A form of kinetic energy in the rotating wheel very quickly is stored in these flywheels. There are two different styles of applications with this technology. The first is a high-speed flywheel system with a rotation speed of $50000 \mathrm{rpm}$ and is used in electric vehicles and similar areas where size and weight are decisive. Secondary types operate at lower speeds of $7000 \mathrm{rpm}$ and are relatively larger. Flywheels of the secondary type can have diameters of one meter [7]. In the first applications, while the mechanical energy is stored and given as a kinetic energy in case of need, today, with the help of the developing technology, the use of electrical - mechanical transformations increases with the applications and the usage areas are becoming more common. As for the first use, mechanical - mechanical transformations consisted of a rotating iron mass, while today mechanical - electrical transformations consist of revolving mass of lighter materials. At the entrance it takes energy as electrical energy and transforms it into kinetic energy by motor operation. In case of need, this energy is output by the generator again as electrical energy output [15].

\subsubsection{Compressed air energy storage}

Compressed air systems are used to move the compressors that transmit electrical energy to the containers under high pressure and then to supply the energy under pressure in a piston or turbine when needed (Figure 1). CAES systems store compressed air in geological structures such as underground water layers, abandoned salt or other mineral deposits. Generally, CAES systems have a large operating cost for small scale requirements. In practice, the smallest CAES energy storage unit has $10 \mathrm{MW}$ of power and $100 \mathrm{MW} / \mathrm{s}$ of energy production. Compressed air energy storage systems have higher power and energy density than pressurized water storage systems [7].

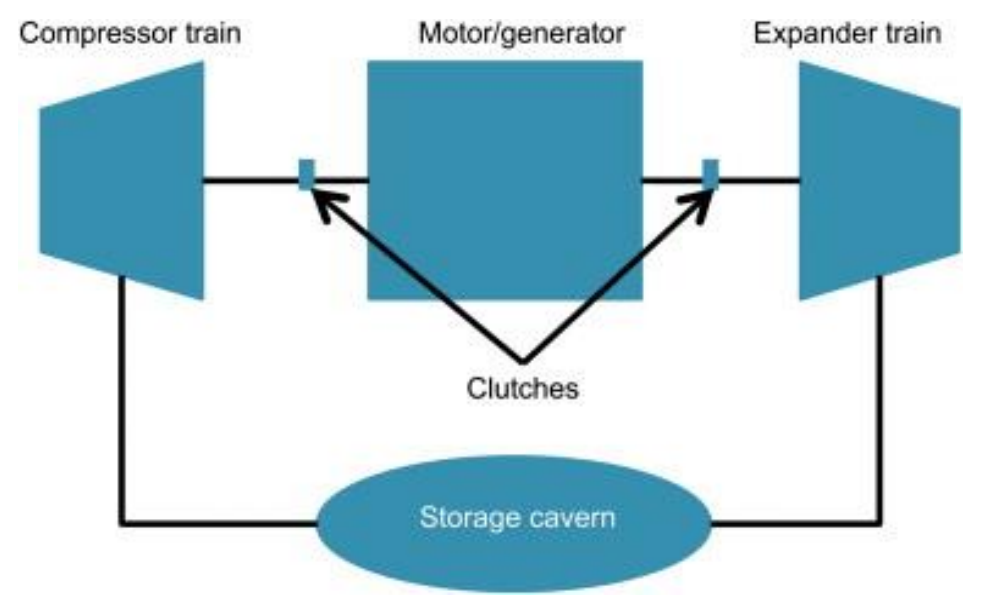

Figure 1. Schematic representation of a Compressed Air Energy Storage (CAES) System [12] 
The compressed air storage system enables the storage of energy in an air storage tank by means of a compressor in the absence of intensive use of energy, ie in the case of low use. In order to be fitted to the energy turbine, a special holder is required to provide a double command to provide a command for the generator, one for the loading command and the other for a discharging command. Three types of reservoirs generally include: physical formations of natural underground sources, molten salt solutions and rocks. During charging, compressed air is sent to the reservoir while the power plant generator is reversed with the compressor to provide mechanical energy. When the plant is discharged, the compressed air is used to operate the internal combustion turbines [14].

\subsubsection{Tank pump systems}

Although it is currently used in all of the commercial life, the oldest and the largest energy storage technology reservoir pump systems can have a capacity of $1000 \mathrm{MW}$ or more with the existing equipment. In addition, there are two vertically positioned water reservoirs in conventional reservoir systems.

Although the mechanical storage technology of reservoir pump systems is referred to as the most electrical production. When the electricity is used very little, the water is pumped from low to high and the energy is stored and electricity can be generated again when needed. In some high-level hydraulic dams, storage capacities are increased by using pumped-in systems, thus increasing the amount of energy they will produce. Cavity or mine caverns are used for the flow of Systems with Underground Hopper Pump but this way is expensive. If there is a suitable place in the open sea, it can be used by transporting seawater from low reservoir to high reservoir [25].

\subsection{Magnetic energy storage}

The energy can be reversibly stored in the electric field in a so-called capacitor. There are two general types of devices in this area and they have a very wide scale according to practical usage characteristics such as the amount of energy they store, energy absorption and oscillation values [10].

\subsubsection{Super magnetic energy storage}

SMES systems store energy with a superconducting magnetic coil immersed in a very cold liquid such as liquid helium in a very well insulated bottle. The resistors of the superconducting magnetic coils are 0 , so the electric current will not decrease over time once it starts to flow. The coils are not too large. In SMES, the power is stored by magnetically rotating the DC electric current in the coil. This is done in reverse. The advantages of Somers are efficient, robust, reliable and quiet operation. In micro-second speed and very good voltage regulation, the bridging time is $1 \mathrm{sn} 60 \mathrm{sec}$, the installation time is 3 weeks and the efficiency is $90 \%$. The disadvantages of SMES are that they need cooling, high cost and are sensitive to temperature [16].

In these systems, storage mode is the storage of energy in the magnetic field formed by flowing current in the superconducting coil. In the superconducting magnetic energy storage (SMES) system are basically the following components; superconducting coil (cryostat), energy conversion system (inside and outside for the transfer of energy) and cooling system. The advantages of SMES are very high efficiency (approx. 97-98\%), responding to requests in a very short time $(20$ verme $30 \mathrm{~ms})$, independent use of active and reactive power, long life. It is the storage technique used in many fields with the features mentioned above. In particular, it can be used for important points such as peak loads, frequency control, system stability and load flow control in the electrical grid system and it can be called the only storage unit that has been separated from other storage techniques [17].

Typically super capacitors are isolated into two classes. To be specific; They are twofold layer capacitors and electrochemical capacitors. The twofold layer capacitor depends as soon as possible layer instrument and works on the standard of isolating the voltage from the cathode surface of the actuated carbon or the interface between the carbon fiber and the electrolytic arrangement. Electrochemical capacitors depend on a fast oxidation decrease (REDOKS) response. Electrochemical capacitors incorporate metal oxide super capacitors and conductive polymer super capacitors. They utilize every one of them to create limit dependent on the reversible REDOKS response on the anode surface or the terminal potential. Limits are essentially founded on the utilization of dynamic anode material [16]. 


\subsection{Thermal energy storage}

There are two diverse warm capacity systems. The first is the vitality put away by the strong and/or fluid materials together with the temperature rise. The other is warm capacity, which causes a stage change of materials without a concoction change [10].

The capacity of warm vitality permits the capacity of hot or cool for later utilize, while keeping up the equalization of temperature, time, space or power distinction between power age and utilization, with regards to supply tüketim request. It very well may be utilized for two stockpiling. Squander warm, sun oriented vitality and geothermal vitality, and so on warmth source frameworks are required [18].

\subsection{Fuel cells and hydrogen storage}

Fuel cells, just like batteries, are basically electrochemical conversion devices and convert the energy of the fuel they use into electrical energy through electrochemical conversion pathways. Unlike batteries, fuel cells get their fuel from the outside of a source. However, the batteries contain the materials that will undergo an electrochemical transformation. A fuel cell has three elements and is anode, cathode and electrolyte solution respectively. According to the weather or the condition oxygen through the cathode, hydrogen also passes through the anode. During this process, when the ions are dissociated into their atoms, electrons flow through the cathode through the electrolyte. Electricity is generated by the external circuit flow of electrons. Water is obtained by reacting electrons with oxygen and hydrogen ions in the cathode [10].

Fuel cell, specific energy value in terms of batteries a higher value, while the specific power It has a worse value. That too beyond, fuel cells are quite expensive and cannot adapt quickly to load changes [3].

U.S. Department of Energy says, fuel cells are classified according to the electrolyte type. While many different types of fuel cells are present or in development, commonly used fuel cells are as follows:

- Proton Exchange Fuel Cell (PEFC)

- Alkaline Fuel Cell (AFC)

- Phosphoric Acid Fuel Cell (PAFC)

- Molten carbonate fuel cell (MCFC)

- Solid Oxide Fuel Cell (SOFC).

In fact, the electrolyte directly determines the operating temperature of the cell. Therefore, the temperature of the fuel cells can also be differentiated. Fuel cells are the systems that produce electrical energy by consuming the hydrogen stored in different types of storage tanks if needed. Although fuel cells today have big problems, it promises future. Hydrogen storage systems are seen as one of the most important energy storage methods of the future [17].

Hydrogen can be stored in different types, different environments. The most important hydrogen storage techniques:

- Storage of Hydrogen in the Gas Phase in High Pressure Tanks

- Storage of Hydrogen in Liquid Phase in Insulated Tanks

- Protonization of Hydrogen in Solids in Metal Hydride Tubes

- Other Hydrogen Storage Approaches

Thermal storage is very important in terms of energy efficiency and sustainability of energy. Nowadays, studies on this subject are continuing rapidly and the main storage methods used in terms of application are given below.

- Storage in solids

- Storage in liquids

- Seasonal storage

- Chemical storage

- Storage with phase change materials 


\section{Discussion}

The comparison of the characteristics of large scale energy storage systems is given in Table 2. According to the data in this table, compressed air storage method is the most economical method in terms of investment cost. The most ideal method for considering the capacity and life is hydropower storage method [2].

Table 2 Comparison of properties of large scale energy storage systems [2]

\begin{tabular}{|c|c|c|c|c|c|c|c|}
\hline $\begin{array}{l}\text { Way of } \\
\text { Storage }\end{array}$ & $\begin{array}{l}\text { Fuel } \\
\text { Cell }\end{array}$ & $\begin{array}{l}\text { Flywheel } \\
\text { (low } \\
\text { speed) }\end{array}$ & $\begin{array}{l}\text { Flywheel } \\
\text { (high } \\
\text { speed) }\end{array}$ & $\begin{array}{l}\text { Hydroelectric } \\
\text { Storage }\end{array}$ & $\begin{array}{l}\text { Compressed } \\
\text { Air Storage }\end{array}$ & $\begin{array}{l}\text { Super } \\
\text { Magnetic } \\
\text { Energy } \\
\text { Storage } \\
\end{array}$ & $\begin{array}{l}\text { Super } \\
\text { Capasitor }\end{array}$ \\
\hline $\begin{array}{l}\text { Investment } \\
\text { Cost/MW }\end{array}$ & $\$ 15.000$ & $\$ 300.000$ & $\begin{array}{c}\$ \$ \\
25.000 .000\end{array}$ & $\$ 7.000$ & $\$ 2.000$ & $\$ 10.000$ & $\begin{array}{c}\$ \$ \\
28.000 .000\end{array}$ \\
\hline $\begin{array}{l}\text { Weight/ } \\
\text { MWh }\end{array}$ & $30 \mathrm{~kg}$ & $7.500 \mathrm{~kg}$ & $3.000 \mathrm{~kg}$ & - & $2,5 \mathrm{~kg}$ & $10 \mathrm{~kg}$ & $10.000 \mathrm{~kg}$ \\
\hline Efficiency & $0,45-08$ & 0,9 & 0,93 & 0,8 & 0,85 & 0,97 & 0,95 \\
\hline $\begin{array}{l}\text { Maintenance } \\
\text { Cost/MWh }\end{array}$ & $\$ 10$ & $\$ 3$ & $\$ 4$ & $\$ 4$ & $\$ 3$ & $\$ 1$ & $\$ 5$ \\
\hline Capacity & $\begin{array}{l}0,3- \\
2.000 \\
\mathrm{kWh}\end{array}$ & $50 \mathrm{kWh}$ & $750 \mathrm{kWh}$ & $22.000 \mathrm{kWh}$ & $2.400 \mathrm{kWh}$ & $0,8 \mathrm{kWh}$ & $0,5 \mathrm{kWh}$ \\
\hline Life span & $\begin{array}{l}10 \\
\text { years }\end{array}$ & 20 years & 20 years & 40 years & 30 years & 40 years & 40 years \\
\hline
\end{tabular}

The main objective of the energy efficient approach is to apply the techniques of delaying the shift as far as possible to energy-based systems purchased from systems based on natural resources. Such improvements in the building's energy performance increase fuel cell and photovoltaic placement in the container. Thus, building with energy generators integrated into the shell components will gain a less energy consuming feature. As stated above, such practices are of course in the research phase and they will be waited for a while to lower their prices and gain commercial value. From this point of view, systems related to passive solar heating and cooling as well as natural lighting and ventilation of the building will be activated.

The traditional design, which consists of discrete processes carried out in the form of the construction of the architectural project and the addition of other systems above, prevents the building to achieve a good solution in terms of initial investment cost and energy consumption. In order to reduce such drawbacks, interdisciplinary teamwork needs to be done from the first steps of design.

The main objective of the different disciplines that contribute to the production of buildings should be to use energy efficiently while preparing the places where they will live more comfortably. For this, it seems necessary to find an energy engineer or energy consultant, especially in large buildings. Thus, the design of buildings that are suitable for climate, benefit as much as possible from renewable energy sources and consume less energy will be easier and zero energy buildings can design.

\section{Conclusion}

As mentioned at the beginning, a single energy storage technique is not always suitable for every application. To determine which methods will be used, preliminary study and cost analysis should be done properly and the most accurate method should be selected carefully. Today, the orientation to renewable energy also necessitates the use of energy storage technologies, which increases the need for new, more efficient storage technologies. Although many energy storage systems have been developed, none of them has exactly the features needed by all applications. In an application to be used, which storage technology to select can be determined by comparing the common key features of the technologies. Due to the small number of systems in practice and the commercial immaturity of certain technologies, it is necessary to make some preliminary assumptions [2]. Storage technologies differ from each other technically specific energy, specific power values, energy capacity and maximum storage time. On the economic side, the costs of operation and 
installation vary greatly. When a new selection is made, the suitability of each energy storage system should be carefully analyzed.

\section{References}

[1] A. Sarı, "'Faz Değişimi Youluyla Isı1 Enerjinin Depolanması ve Bu Alanda Yapılan Çalışmalar"," in Kimya Lisans Öğrencileri Araştırma Projesi Çalıştayı, Çanakkale, 2011.

[2] M. Kozak, S. Kozak, "Energy Storage Method," in SDU International Technologic Science, pp.17-29, Vol.4, No2, November 2012.

[3] J. K. M. C. A. A. L. Y. Riberio F.P., "Energy Storage Systems for Advanced Power Applications," in Proceedings of the IEEE, pp. 1744-1756, 2001.

[4] Z. P., "Thermal energy storage and retrieval characteristics of a moltensalt latent heat thermal energy storage system," in Applied Energy, pp. 255-271, 2016.

[5] Ö. M., "Bir Enerji Depolama Sisteminin Tasarımı ve Çalışma Parametrelerinin Deneysel ve Sayısal Olarak İncelenmesi," İzmir, 2010.

[6] M. Boztepe, "Enerji Depolama," 2006. [Online]. Available: http://electronics.ege.edu.tr/boztepe/cgibin/load.cgi?gee591_lecture6.pdf. [Accessed 1011 2018].

[7] S. W. G. Wills H., Distributed Generation Planning and Evaluation, New York: Marcel Dekker Inc, 2000.

[8] I. E. Agency, "Technology Road Map: Energy Storage," 2014.

[9] G. Y. Landry M., "Energy Storage: Technology Applications and Policy Options," in Energy Procedia, pp. 315-320, 2015.

[10] H. R. A., Energy Storage, USA: Springer New York Heidelberg Dordrecht London, 2010.

[11] B. H. L. M. Bolund B., "Flywheel energy and power storage systems," in Renewable and Sustainable Energy Reviews, pp. 235-258, 2007.

[12] A. J. Fertig E., "Economics of compressed air energy storage to integrate windpower: a case study in ERCOT," in Energy POl., pp. 2330-2342, 2011.

[13] A.-H. L. M. A. M. M. Rehmana S., "Pumped hydro energy storage system: A technological review," in Renewable and Sustainable Energy Reviews, pp. 586-598, 2015.

[14] R. B. Schnaiker, Electr. Power Res. Inst., CA: CAESscope, 1990.

[15] B. P. Bryan, J. A. Andrews, "Advence in Flywheel Energy Storages Systems," Tezas, 2004.

[16] K. Sahay, B. Dwivedi, "Energy Storage Technology for Performance Enhancement of Power Systems," Electrical Power Quality \& Utilization Magazine, no. 4, pp. 1-12, 2009.

[17] S. Kuşdoğan, G. Kurt, A. Arsoy, "Süperiletken manyetik enerji depolama sisteminin incelenmesi ve teknolojik değerlendirilmesi," 2002.

[18] A. L. F., "Reference Module in Earth Systems and Environmental Sciences," in Thermal Energy Storage, pp. 211-253, 2012.

[19] C. Daniel and J. O. Besenhard, Handbook of Battery Materials. Second Edition, U.S.A.: Wiley-VCH Verlag GmbH\& Co., 2011.

[20] D. Linden, T. B. Reddy, Handbook of Batteries, New York, 2002.

[21] R. Hammerschlag, C. P. Schaber, "Energy Storage Technologies," Energy Conversion, Taylor \& Francis Group, 2007.

[22] M. Broussely, G. Pistoia, Industrial Applications of Batteries, Elsevier, 2007.

[23] H. A. Kiehne, M. Dekker, Battery Technology Handbook, New York, 2003.

[24] H. Paksoy, H. Evliya, B. Turgut, M. Mazman, "Alternatif Enerji Kaynaklarının Termal Enerji Depolama ile Değerlendirilmesi," in Enerji Kongresi, Antalya, 2011.

[25] B. Yavuz, "Enerji Depolama Sistemlerinin Modellenmesi ve Analizi," in Yıldız Teknik Üniversitesi, Fen Bilimleri Enstitüsü,, İstanbul, 2011. 